\title{
Nutritional defects in patients with malabsorption
}

\section{By C. F. McCarthy, Department of Medicine and Gastroenterology, Regional Hospital and University College, Galway, Republic of Ireland}

In developed societies nutritional deficiencies are often due to malabsorption. Most causes of malabsorption are related to one or more of the following: ( 1 ) mucosal damage, (2) bile salt deficiency, (3) stagnant loop (blind loop) syndrome, (4) deficiency of digestive enzymes, (5) operations on the gastrointestinal tract, (6) transport defects.

More than one mechanism may be operative in some of the disorders producing malabsorption, for example malabsorption in patients with mucosal damage may be partly due to deficiency of disaccharidase enzymes as well as to the direct effect of the damage to the mucosa. The common nutritional deficiencies seen are: ( 1 ) anaemia, (2) oedema, (3) bone disease, (4) bleeding tendencies.

Anaemia in patients with malabsorption is commonly caused by iron or folate deficiency or a combination of these. More rarely anaemia may be due to vitamin $B_{12}$ deficiency, particularly in conditions where the terminal ileum is resected or there is bacterial contamination of the small intestine. Fe deficiency may be due to failure to absorb dietary Fe (Badenoch \& Callender, 1954, 1960; McGuigan \& Volwiler, 1964) and possibly also to loss of $\mathrm{Fe}$ when the rate of desquamation of intestinal cells is increased (Sutton, Baird, Stewart \& Coghill, 1970). Malabsorption of folate may also be demonstrated where there is mucosal damage (Girdwood, 1953; Anderson, Belcher, Chanarin \& Mollin, 1960; Hoffbrand, Douglas, Fry \& Stewart, 1970). Very rarely pyridoxine deficiency may be important (Dawson, Holdsworth \& Pitcher, 1964).

Oedema is caused by hypoproteinaemia, to which many mechanisms may contribute; failure to absorb amino acids and peptides, loss of protein from the damaged intestine, metabolism of amino acids by bacteria in the blind loop syndrome, and defective hepatic synthesis of albumin following malabsorption are all relevant in considering the pathogenesis of hypoproteinaemia.

Bone disease is more often in the form of osteomalacia than of osteoporosis, at least when clinical symptoms occur. Malabsorption of vitamin D is at least partly responsible.

Bleeding caused by failure to absorb vitamin $\mathrm{K}$ is a less common manifestation of malabsorption.

In adult gastroenterological practice in Ireland by far the commonest cause of malabsorption is coeliac disease. During a 3 -year period, fifty-eight patients with adult coeliac disease, and only six with other causes of malabsorption, were seen. These six included patients with radiation disease of the small intestine, diverticulosis of the small intestine and fibrocystic disease of the pancreas. 
The incidence of coeliac disease in the west of Ireland (Mylotte, Egan-Mitchell, McCarthy \& McNicholl, 1973) is higher than has been reported in the UK (Davidson \& Fountain, 1950; Carter, Sheldon \& Walker, r 959; McCrae, 1969). In the west of Ireland the incidence is between one in 300 and one in 450 of the population. The studies by the Medico-Social Research Board (O'Reilly, Murphy, McLaughlin, Bradshaw \& Dean, 1974), indicating that the hospital admission rate for coeliac disease in the west of Ireland is similar to that in the other areas of the country served by teaching hospitals, suggest that there is a high incidence of coeliac disease throughout the country. Of first-degree relatives of patients with coeliac disease, $12 \%$ are found also to have the disease (Mylotte, Egan-Mitchell, Fottrell, McNicholl \& McCarthy, 1974). Thus if an adult presents with a nutritional deficiency in this country, the most likely cause is coeliac disease.

Usually several deficiencies are present and often diarrhoea gives a clue that malabsorption is responsible for the deficiency. Sometimes this is not so: a I5- $_{5}$ year-old girl presented with anaemia, the haemoglobin being $86 \mathrm{~g} / 1$, and the blood film showed a dimorphic picture owing to a deficiency of $F e$ and folic acid. She had no diarrhoea and was certainly not undernourished, but a jejunal biopsy showed the classical appearance of coeliac disease. Another patient presented with bone pain and minimal diarrhoea: X-ray examination revealed changes typical of osteomalacia, and the jejunal biopsy again was flat. On the other hand, another patient presented with tetany, bone pain, oedema, anaemia and marked diarrhoea, and also had a flat jejunal biopsy.

The mechanism of malabsorption in coeliac disease is largely explained by a combination of cellular damage and reduction of the absorptive surface of the intestine. This reduction of surface area occurs at two levels, both gross and microscopic. The appearance under the electron microscope is shown in Plate $\mathrm{I}$.

There is clearly genetic susceptibility in some if not all cases of coeliac disease (Mylotte et al. 1974). This genetic susceptibility is in part identified by the presence of histocompatibility antigens (HLA) 1, 8 and is (Falchuk, Rogentine \& Strober, 1972; Stokes, Asquith, Holmes, Mackintosh \& Cooke, 1972). In our patients, too, HLA I and 8 predominate in those with coeliac disease. Twelve of the fourteen patients tested had HLA 8. Although HLA 1 or 8 is present in $80 \%$ of coeliacs, it is also present in $20 \%$ of the normal population. Other genetic markers looked at did not help in identifying the carriers of the coeliac gene (Mylotte et al. 1974). Transmission of the gene is also ill-defined.

Against this genetic background, a component of gliadin or the whole gliadin molecule damages the intestinal mucosa to produce the characteristic changes. Whether this is damage by an immune mechanism or due to enzyme deficiency is debatable. Recent evidence (Phelan, McCarthy, Stevens, McNicholl \& Fottrell, 1974) suggests that the carbohydrate portion of gliadin plays an important part in the pathogenesis of coeliac disease.

We have given gliadin, from which the carbohydrate has been removed, to four coeliac patients in remission. The effect of the carbohydrate-free gliadin on the patients was studied in two ways, first by observing the alteration produced, after $5 \mathrm{~d}$ feeding, on oral xylose-tolerance tests, and secondly by histological 

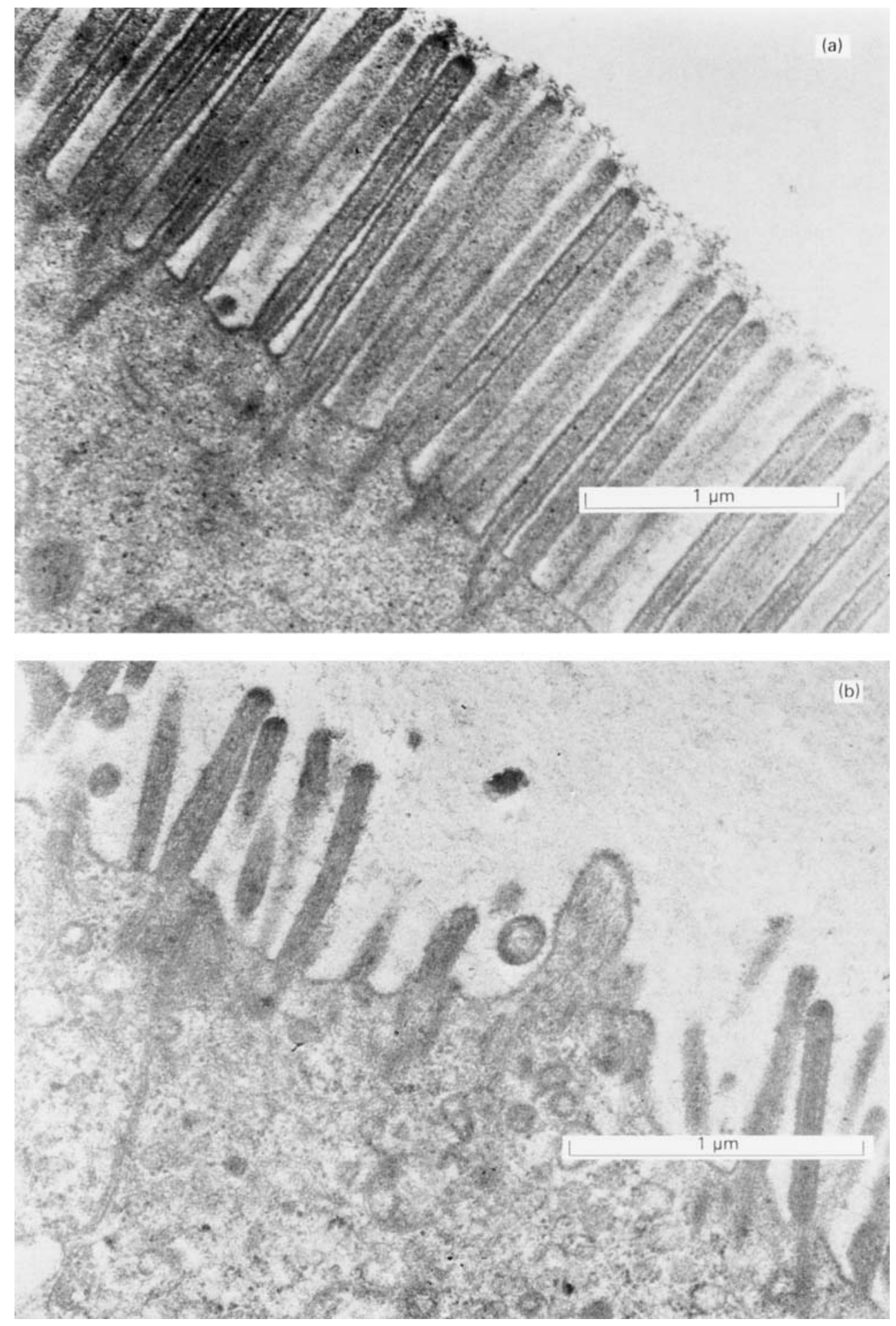

Plate I. Electron micrographs of intestinal enterocyte surface of: (a) normal subject; (b) subject suffering from coeliac disease. 
examination of the intestinal mucosa. The xylose-tolerance tests were only used in patients in whom it had been demonstrated on a previous occasion that feeding of whole gliadin produced a fall in the absorption of xylose. Thus each patient had a xylose-tolerance test carried out and was then given gliadin for a period of $5 \mathrm{~d} ;$ a repeat test showed a fall in the absorption of xylose. When the patient's xylosetolerance test had recovered, often some months later, the patient was given a gliadin fraction from which carbohydrate had been removed. In none of the four patients was depression of xylose absorption observed when carbohydrate-free gliadin was given although all showed a fall when whole gliadin was given. These four patients also had jejunal biopsies before and after receiving the carbohydratefree gliadin. In none was histological change observed after $5 \mathrm{~d}$ : the number of intraepithelial lymphocytes and the electron-microscopic appearance did not alter (J. Phelan, F. M. Stevens, P. F. Fottrell, B. McNicholl \& C. F. McCarthy, unpublished results).

The carbohydrate portion of gliadin, which consists of glucose, galactose, xylose and arabinose, was removed by interaction with an enzyme preparation from Aspergillus niger. As far as could be determined the protein structure of gliadin was not altered.

The observation that the carbohydrate portion is related to toxicity is consistent with the finding that crude papain (EC 3.4.4.10), but not purified papain, removes the toxicity from gliadin (Kranich \& Mohn, 1959; Messer, Anderson \& Hubbard, 1964). Crude but not purified papain contains carbohydrase activity (J. Phelan, personal communication). If the carbohydrate portion's toxicity is confirmed, it is a relatively simple matter to include an enzyme in the baking process which will remove the carbohydrate from the protein without greatly altering the qualities of gluten so essential for baking.

Financial assistance from the Wellcome Trust, the Medical Research Council of Ireland, the Western Health Board and Bristol Chemicals is gratefully acknowledged. I also thank Dr Fiona Stevens for her help in preparing this paper.

\section{REFERENCES}

Anderson, B. B., Belcher, E. H., Chanarin, I. \& Mollin, D. L. (1960). Br. F. Haemat. 6, 439.

Badenoch, J. \& Callender, S. T. (1954). Blood 9, 123.

Badenoch, J. \& Callender, S. T. (1960). Lancet i, 192.

Carter, C., Sheldon, W. \& Walker, C. (1959). Ann. hum. Genet. $23,226$.

Davidson, S. S. P. \& Fountain, J. R. (1950). Br. Med. F. i, 1 I57.

Dawson, A. M., Holdsworth, C. D. \& Pitcher, C. S. (I964). Gut 5, 304.

Falchul, J. M., Rogentine, G. N. \& Strober, W. (1972). J. clin. Invest. 51, 1602.

Girdwood, R. H. (1953). Lancet ii, 53 .

Hoffbrand, A. V., Douglas, A. P., Fry, L. \& Stewart, J. S. (1970). Br. med. J. iv, 85.

Kranich, H. C. \& Mohn, G. (1959). Helv. paediat. Acta $14,124$.

McCrae, W. M. (1969). F. med. Genet. 6, 129.

MeGuigan, J. E. \& Volwiler, W. (1964). Gastroenterology 47, 636 .

Messer, M., Anderson, C. M. \& Hubbard, L. (1964). Gut 5, 295.

Mylotte, M. J., Egan-Mitchell, B., Fottrell, P. F., McNicholl, B. \& McCarthy, C. F. (1974). Q. $f l$ Med. 43, 359.

Mylotte, M. J., Egan-Mitchell, B., McCarthy, C. F. \& McNicholl, B. (1973). Br. med. J. i, 703. 
O'Reilly, D., Murphy, J., McLaughlin, J., Bradshaw, J. \& Dean, G. (1974). Int. J. Epidemiology 3, 247.

Phelan, J. J., McCarthy, C. F., Stevens, F. M., McNicholl, B. \& Fottrell, P. F. (1974). Proc. 2nd int. Coeliac Symp. p. 60.

Stokes, P. L., Asquith, P., Holmes, G. K. T., Mackintosh, P. \& Cooke, W. T. (1972). Lancet ii, 162.

Sutton, D. R., Baird, I. M., Stewart, J. S. \& Coghill, N. F. (1970). Lancet ii, $3^{87}$. 